\title{
Meningkatkan Penguasaan Kosakata Anak Usia Dini melalui Puisi Lagu Anak
}

\author{
DINAR NUR INTEN \\ Program Studi Pendidikan Guru Pendidikan Anak Usia Dini \\ Universitas Islam Bandung \\ Email: dinar_nurinten@yahoo.com
}

DOI: https://doi.org/10.29313/ga.v2i2.4437

\begin{abstract}
Language plays a very important role in a child's life. From birth to the world, children have known and introduced language by those around them. To develop the language's ability for children it is inseparable from vocabulary mastery, the more vocabulary they have, the better their language skills and children's communication. Early childhood learning must be fun and interesting so that it will give birth to learning that is meaningful and remembered by the child throughout his life. Therefore researchers chose song poetry techniques to introduce vocabulary for early childhood especially those aged 2-4 years with qualitative research methods. Poetry and song will be one of the technique to introduce language and vocabulary that are suitable for children's development because song poetry is full of word games, songs, and movements that will deliver the child comfortably and enjoy the learning that is carried out.
\end{abstract}

Keywords: Vocabulary, Early Childhood, Song Poetry.

\begin{abstract}
Abstrak
Bahasa memegang peranan yang sangat penting dalam kehidupan anak. Sejak lahir ke dunia anak telah mengenal dan diperkenalkan bahasa oleh orang di sekitarnya. Untuk mengembangkan kemampuan berbahasanya anak tidak terlepas dari penguasaan kosakata, semakin banyak kosakata yang dimilikinya maka kemampuan berbahasa dan komunikasi anakpun akan semakin baik. Pembelajaran anak usia dini haruslah menyenangkan dan menarik sehingga akan melahirkan pembelajaran yang bermakna dan diingat oleh anak sepanjang hidupnya. Oleh karena itu peneliti memilih teknik puisi lagu untuk mengenalkan kosakata untuk anak usia dini utamanya usia 2-4 tahun dengan metode penelitian kualitatif. Puisi dan lagu akan menjadi salah satu teknik mengenalkan bahasa dan kosakata yang sesuai dengan perkembangan anak, karena puisi lagu sarat dengan permainan kata, nyanyian dan gerakan yang akan mengantarkan anak nyaman dan menikmati pembelajaran yang dilaksanakan.
\end{abstract}

Kata Kunci: Kosakata, Anak Usia Dini, Puisi Lagu. 


\section{Pendahuluan}

Anak usia dini adalah sosok individu yang sedang mengalami perkembangan yang sangat pesat dalam berbagai aspek perkembangan yang sangat dibutuhkan bagi kehidupannya. Anak usia dini adalah anak yang berusia 0-8 tahun, dimana dia berada dimasa keemasan (golden age) yaitu masa yang sangat peka terhadap berbagai hal rangsangan yang diberikan kepadanya karena masa ini merupakan masa terjadinya pematangan fungsi-fungsi fisik dan psikis sehingga anak siap merespon berbagai hal demi mewujudkan tugas-tugas perkembangannya. Untuk itulah seyogyanya anak-anak diberikan pendidikan yang sesuai dengan perkembangannya dan pendidikan yang sesuai dengan kebutuhan dan minat anak agar pertumbuhan dan perkembanganya tercapai secara optimal.

Salah satu aspek perkembangan yang memiliki peranan penting bagi kehidupan anak adalah bahasa. Bahasa merupakan alat utama yang diandalkan manusia dalam kehidupan sehari-hari dan dalam pergaulan serta komunikasi dengan sesamanya. Keberhasilan manusia dalam pergaulan sehari-hari dan dalam mencapai tujuan, sangat tergantung pada kemampuan dan keterampilan dalam berbahasa. Anak akan mampu berbahasa dengan baik apabila kosakata yang dimilikinya banyak, melalui kosakata yang banyak anak akan mampu berkomunikasi dengan baik pula. Kualitas keterampilan berbahasa seseorang tergantung kepada kuantitas dan kualitas kosakata yang dimilikinya (Tarigan, 1984:2).

Pada usia 18 bulan bayi dapat mengucapkan 50 kata, tetapi pada usia 2 tahun bayi telah dapat mengucapkan 200 kata (Santrock, 2007:358). Peningkatan jumlah kosakata yang cepat ini dimulai pada usia kirakira 18 bulan, disebut ledakan kosakata (vocabulary spurt) (Bloom, Lifter dan Broughton, 1985). Sedangkan pada usia 5-6 tahun jumlah kosakata yang dimiliki anak adalah 2500 kosakata. Hasil penelitian Dyah Rahmawati dkk (2018:10) menyatakan kualitas ragam kosakata yang dikuasai anak prasekolah dipengaruhi oleh beberapa faktor diantaranya adalah faktor usia, jenis kelamin, kondisi lingkungan keluarga dan perbedaan masukan (input) yang diterima oleh anak. Oleh karena itu perlu adanya suatu kegiatan yang dapat merangsang bertambahnya jumlah kosakata anak. Sehingga anak dapat memiliki jumlah kosakata yang optimal sesuai dengan usianya serta mampu menggunakannya untuk berkomunikasi menyampaikan ide-ide dan pemikirannya terhadap orang disekitarnya.

$$
\text { Dalam berkomunikasi anak }
$$
memerlukan kosakata yang cukup banyak, kosakata dapat dimiliki oleh anak apabila lingkungan dimana tempat anak tersebut tinggal memberikan rangsangan yang cukup baik untuk pertumbuhan kosakatanya, terutama keluarga dan orang tuanya. Melalui kegiatan membacakan cerita oleh orang tua yang dilakukan secara berkelanjutan dapat meningkatkan kosakata anak usia dini. Berdasarkan penelitian Inten, (2017:28) mengemukakan rendahnya aktivitas membaca nyaring atau memperdengarkan cerita pada anak oleh orang tua berdampak kurangnya minat anak akan literasi (membaca dan menulis), hal ini di sebabkan kurangnya kosakata yang dimiliki oleh anak dan kurangnya keteladanan dalam keluarga untuk menumbuhkan literasi pada anak sejak dini.

Dalam mengembangkan penguasaan kosakata pada anak usia dini diperlukan pendekatan ataupun cara yang menyenangkan dan menarik bagi anak. sebagian anak merasakan ketakutan dan tidak berani untuk menyampaikan ide dan gagasannya kepada orang lain dikarenakan ketidak nyamana suasana di lingkungannya (Inten, 2017: 122). Oleh karena itu untuk memicu keberanian dan kemampuan anak berbahasa dan berkomunikasi diperlukan sebuah cara atau teknik yang menyenangkan dan dekat dengan dunia anak, salah satu caranya melalui puisi nyanyian anak. Pembelajaran kosakata bahasa Arab melalui teknik gerak dan lagu membuat anak-anak lebih merasakan kebermaknaan, kenyamanan dan antusias dalam mengikutinya (Inten, 2015:7).

Syair lagu atau tembang tidak lain adalah puisi (Nurgiantoro, 2016:103). Jadi lagu dan tembang untuk anak dapat pula disebut sebagai puisi yang dilagukan atau puisi lagu. 
Lagu ataupun nyanyian merupakan suatu hal yang erat kaitannya dengan dunia anak dan hampir semua orang bisa bernyanyi sehingga hal ini dapat menjadi alternatif untuk memperkaya penguasaan kosakata anak usia dini.

Nyanyian yang memiliki pengulangan bunyi pada kata-kata terpilih akan dapat dibangkitkan aspek persajakan dan irama puisi yang menyebabkan puisi menjadi lebih indah dan bermakna serta mudah untuk diikuti oleh anak. Penelitian Inten dkk, Literasi melalui teknik bernyanyi menyatakan bahwa mengenalkan literasi dini dalam hal ini yang dimaksud adalah membaca dan menulis bagi anak usia dini (mengembangkan aspek bahasa) lebih mudah dan menarik bagi anak apabila disampaikan melalui teknik bernyanyi (2016:89).

Tujuan dari penguasaan kosakata melalui puisi menurut Otto (2015:273), yaitu memperluas pemahaman anak terhadap katakata yang memiliki bunyi hampir sama dan pola berirama. Irama dan melodi yang mengikuti kegiatan ini pun akan membantu kefasihan anak dalam bertutur kata. Ketika bahasa tubuh di gabungkan untuk memperjelas syair puisi dan lagu maka pemahaman anak akan makna bahasa tersebut akan lebih kuat dan meluas. Melalui puisi lagu yang di sampaikan secara berulang-ulang kita akan menemui beberapa anak ikut berpartisipasi dalam gerakan dan kemudian ikut menirukan kata-kata dalam lagu puisi tersebut. Hal ini pun selaras dengan penelitian Inten\&Mulyani (2016: 7), melalui igel mang Koko bahasa sunda akan mudah diterima, dipahami dan digunakan oleh anakanak karena selain anak-anak bernyanyi menggunakan bahasa sunda anak-anak pun sekaligus menari atau mempraktekkan gerakan sesuai dengan syair pada kawih yang dinyanyikan.

\section{Kajian Pustaka \\ Penguasaan Kosakata}

Harjono (1988) dalam Jamaris (2005:9) 'mengemukakan bahwa dari semua aspek bahasa asing yang harus dikuasai siswa dalam proses belajar ialah aspek kosakata'. "Penguasaan kosakata seseorang dapat dilihat dari hal-hal berikut:. Ketepatan ucapan, penempatan tekanan dan nada yang sesuai, pilihan kata, dan ketepatan sasaran pembicaraan" (Nurbiana, 2008: 3-6). Sedangkan menurut Izzan (2011:74) " penguasaan kosakata adalah ukuran kemampuan seseorang akan kosakata yang meliputi : tahap pertama adalah membedakan bunyi huruf yang satu dengan yang lainnya, membedakan pelafalan huruf. Tahap kedua, mengenali petanda gramatika, seperti urutan kata, imbuhan dan intonasi. Tahap ketiga, aplikasi yaitu penggunaan kata-kata dalam percakapan dan pemilihan kata yang tepat".

Menurut Al-Khuly (2002) ciri-ciri seorang anak memahami sebuah kata, untuk tingkat usia Taman Kanak-Kanak, anak memahami kata tersebut ketika ia mendengar atau membacanya, anak mampu mengucapkan kata tersebut dengan benar. Pada tingkat usia yang lebih tinggi, anak mampu menuliskan kata dengan benar, mampu menggunakan kata tersebut sesuai konteks serta mampu membaca kata tersebut baik ketika terpisah dari kalimat maupun dalam konteks kalimat.

Anak-anak belajar kosakata dengan dua cara : Pertama, mereka mendengar kata-kata dari orangtua, dari anak-anak yang lebih tua, dari teman sepermainan, dari televisi, dari radio, tempat bermain, toko dan pusat perbelanjaan. Kedua, mereka mengalaminya sendiri : mereka mengatakan benda-benda, mereka memakannya, mereka merabanya, mereka menciumnya, mereka meminumnya. Menurut Slatery dan Willis (2001) ada dua tahap dalam pembelajaran kosakata pada anak usia dini yaitu : 'bicarakan dengan anak tentang nama-nama benda yang akan dipelajari dan mintalah anak-anak untuk menunjukkan bendabenda yang dinamai tadi' ( Balai Bahasa, 2010:2).

Berikut ini lima langkah penting dalam pembelajaran kosakata bagi anak usia dini.

a. Memiliki sumber untuk bertemu dengan kata-kata baru

b. Memiliki gambar (image) jelas baik yang berupa visual maupun audio mengenai bentuk dari kata-kata baru

c. Mempelajari makna kata-kata tersebut 
d. Memiliki kaitan ingatan yang kuat antara bentuk dan makna kata-kata baru tadi

e. Menggunakan kata-kata tersebut (Balai Bahasa UPI : 2010)

f. Kosakata yang digunakan untuk menjelaskan kosakata berikutnya adalah kosakata yang telah dikenal oleh anak, yaitu kosakata yang ada dilingkungan sekitar anak.

Cara anak memepelajari kosakata:

Pertama, mereka mendengar kata-kata tersebut dari:

Orang tua

Anak-anak yang lebuh tua

Teman sepermainan

Televisi dan radio

Tempat bermain

Toko, pusat perbelanjaan.

Kedua, mereka mengalaminya sendiri:

Mereka mengatakan benda-benda

Mereka memakannya

Mereka merabanya

Mereka menciumnya

Mereka meminumnya (Tarigan, 1986:6).

Pembelajaran bahasa utamanya pengenalan kosata pada anak haruslah melalui sebuah konteks pemakaian yang utuh, dan anak dilibatkan secara langsung dalam pengenalan kosata baru tersebut hal ini akan berdampak pada kemampuan anak dalam menguasai kosakata yang baru. Nurgiantoro (2015: 43), mengatakan bahwa anak akan belajar bahasa dengan cepat apabila bahasa atau kosakata yang diperolehnya langsung berada dalam konteks pemakaian sesungguhnya.

\section{Perkembangan Bahasa Anak}

Pada usia 2-2,5 tahun anak sudah bisa mengucapkan empat kata, bisa menyusun kalimat sederhana dan nada tanya sudah sangat jelas. Usia 2,5 - 3 tahun bahasa sudah lancar dan mengerti pembicaraan orang lain. 34 tahun senang mendengar cerita, bisa menguasai bahasa cerita dalam buku. 4-6 tahun berbicara lancar dan untuk usia 6 tahun dapat menggunakan kalimat majemuk dan anak kalimat (Masnipal, 2014:72).

Kemampuan berbicara anak akan semakin optimal pabila anak sering diajak bercakap-cakap. Dengan bercakap-cakap anak akan mendapatkan pengalaman berbahasa, meningkatkan kosakatanya sehingga berkembanglah bahasanya. Menurut Dhinie (2008 : 3.9), anak membutuhkan reinforcement (penguatan), reward (hadiah, pujian), stimulasi, dan model atau contoh yang baik dari orang dewasa agar kemampuannya dalam berbahasa dapat berkembang secara maksimal.

Beberapa ahli sepakat bahwa anak memiliki kemampuan untuk menirukan bahasa orang tua yang dilakukan dengan dua cara yaitu secara spontan dan melalui penugasan dari orang dewasa untuk meniru bahasa tersebut (Dhinie, $2008: 3.7$ ).

Anak akan mampu berbicara dengan baik apabila perbendaharaan kosakata yang dimilikinya cukup banyak. Oleh karena itu stimulasi berbicara lebih baik apabila diberikan sedini mungkin. Beberapa hal yang dapat dilakukan agar balita lancar berbicara, yaitu : ajaklah anak berbicara sesering mungkin dengan berbagai pertanyaan yang dapat memperkaya kosakatanya, deskripsikan benda-benda di dekat anak supaya ia mengenal dan memahaminya, bernyanyi bersama anak, ajak bersosialisasi dengan teman sebayanya (Madyawati, 2016: 85-86).

Salah satu sifat anak adalah meniru berbagai hal yang ada disekitarnya. Menurut Uyu \& Agustin (2011: 38), kemampuan imitasi anak menjadi modal penting dalam perkembangan bahasanya. Anak senang meniru bunyi-bunyi tertentu ataupun ucapan orang-orang disekitarnya.

Perkembangan bahasa batita bisa diperluas dengan lagu-lagu aksi dan permainan yang disertai nyanyian di kelompok kecil atau selama rutinitas harian. Kegiatan ini mendorong mendengarkan dan peniruan aktif, bersama dengan perhatian ritme, pengulangandan intonasi ekspresif (Otto, 2015:189). 


\section{Puisi Lagu Anak}

Syair lagu atau tembang tidak lain adalah puisi ( Nurgiantoro, 2016:103). Jadi lagu dan tembang dapat pula disebut sebagai puisi yang dilagukan, puisi lagu. Melalui permainan perulangan bunyi pada kata-kata terpilih akan dapat dibangkitkan aspek persajakan dan irama puisi yang menyebabkan puisi menjadi indah dan melodis.

Untuk puisi anak ada beberapa hal yang perlu diperhatikan, dianataranya adalah kesederhanaan bahasa dan puisi yang umumnya berbaris pendek dan adanya pengulangan. Hal ini sama dengan pemilihan lagu untuk anak, yang harus menggunakan kata berulang, anak usia dini menyukai syair lagu yang pendek dan berulang-ulang (Inten, $2016: 79$ ).

Menurut Nurgiantoro (2016: 27), gendre puisi anak dapat berwujud puisi-puisi lirik tembang- tembang anak tradisional, lirik-lirik tembang ninabobo, puisi naratif, dan puisi tradisional.

Jenis puisi lain yang dapat disampaikan pada anak adalah : puisi naratif dan puisi personal. Puisi naratif adalah puisi yang di dalamnya mengandung cerita, atau sebaliknya cerita yang dikisahkan melalui puisi. Puisi personal adalah puisi modern yang sengaja di tulis untuk anak-anak baik oleh penulis dewasa maupun anak-anak. puisi ini berbicara terntang alam, ibu dan kebaikan hati ibu, pengorbanan ibu, persahabatan, binatang piaraan dan lainlain (Nurgiantoro, 2016: 27-28).

Teks dan rima akan memperluas kesadaran fonetik anak karena kata-kata berirama menekankan komponen bunyi pada kata. Anak menikmati lagu-lagu pendek, berirama, dan lagu-lagu anak (Otto, 2015 : 189).

Puisi dan lagu dapat digunakan sebagai salah satu alternatif pembelajaran bahasa untuk anak. menurut Otto (2015:273), melalui kegiatan puisi dapat memperluas pemahaman anak terhadap kata-kata yang memiliki bunyi hampir sama dan pola berirama, irama dan melodi yang menyertai kegiatan ini mendukung kefasihan lisan anak.

Puisi lagu untuk anak dapat disesuaikan dengan kurikulum atau tema pembelajaran yang sedang berlangsung. Ketika memilih puisi lagu untuk digunakan anak-anak prasekolah pilihlah puisi lagu yang familiar untuk anakanak dan memiliki susunan sintaksis sederhanaserta pilihlah puisi lagu yang berkoordinasi dengan kurikulum sekolah (Otto, 2015: 273).

Anak menyenangi permainan kata dengan suaranya atau yang disamapaikan melalui nyayian, anak pun senang mencari makna dari kata yang mereka dengar. Menurut Beaty (2013: 325), semua anak bermain dengan kata terutama di awal tahap perkembangan bahasa, anak-anak yang terlibat pada kegiatan berirama atau puisi pada usia dini akan berhasil dalam kegiatan membaca.

\section{Metode Penelitian}

Metode yang digunakan dalam penelitian ini adalah kualitatif yang lebih menekankan terhadap analisis berdasarkan kajian literatur. Kajian literatur yaitu penelitian yang dilakukan berdasarkan referensi ilmiah yang ada. Hal ini untuk melihat adanya korelasi antara data yang berupa teori-teori dari buku, artikel ilmiah ataupun hasil-hasil penelitian di jurnal-jurnal dengan puisi lagu anak-anak yang diangkat penulis.

Dalam penelitian ini penulis mengkaji 5 buah puisi lagu anak yang populer dan sesuai dengan perkembangan anak usia 3-4 tahun atau usia kelompok bermain. Dimana pada usia ini anak-anak sangat membutuhkan kosakata yang cukup banyak untuk mengembangkan kemampuan bahasa dan komunikasinya.

\section{Pembahasan}

Pada usia awal anak anak belum mengenal tulisan dan anak belum bisa membaca tetapi sudah dapat menerima rangsangan, gerak dan mendengar dengan baik, maka melalui gerak, dan suara bahasa dapat dikenalkan dengan baik pada anak agar mereka memiliki kosakata yang banyak sehingga mampu berkomunikasi dengan baik. Oleh karena itu maka dipilihlah puisi lagu sebagai cara untuk menyampaikan bahasa pada anak, dengan puisi pelafalan kosakata dan syair lagu dapat disampaikan dengan jelas 
sedangkan melalui lagu anak akan merasakan kenyamanan dan ketenangan. Menurut Nurgiantoro ( 2015: 102), puisi yang diberikan pada anak, maka puisi itu adalah puisi-puisi yang dilagukan yaitu puisi lagu.

Di bawah ini merupakan puisi lagu yang dikenalkan pada anak-anak mulai usia 2 tahun sampai dengan 4 tahun. Beberapa kosakata dapat dikenalkan pada anak melalui pelafalan guru ataupun orang tua yang jelas dan benar, serta agar anak dapat memahami makna kata dari syair puisi lagu yang dinyanyikan maka selain bernyanyi guru ataupun orang tua dapat sekaligus mencontohkan gerakan sesuai makna kata yang ada dalam syair puisi lagu.

Lagu-lagu di bawah ini disebut puisi lagu karena akhirannya memiliki fonem yang sama, ada beberapa baris yang merupakan pengulangan baris sekaligus berupa tiruan bunyi (onomatope), dan ada beberapa puisi sajak yang memiliki efek eksploitasi tiruan bunyi, dan larik pada beberapa syair lagu memiliki asonansi dan aliterasi. Serta bait-bait puisi lagu di bawah ini sederhana dan pendek sehingga mudah dicerna dan diingat oleh anak.

\section{Bangun Tidur \\ Cip : Pak Kasur \\ Bangun tidur ku terus mandi \\ Tidak lupa menggosok gigi \\ Habis mandi ku tolong ibu \\ Membersihkan tempat tidurku}

Pada puisi lagu Bangun Tidur ciptaan pak Kasur di atas, di lihat dari sudut kosakata : mengenalkan pada anak tahapan kegiatan setelah bangun tidur, yaitu: mandi, menggosok gigi setelah beres membersihkan diri maka anak berlanjut untuk membiasakan diri untuk membereskan tempat tidur. Untuk anak-anak usia 2 dan 3 tahun dapat di kenalkan kata tidur, mandi, tempat tidur dan gosok gigi serta sekaligus mengenalkan bentuk-bentuk huruf yang ada pada puisi lagu tersebut, yaitu maksudnya puisi lagu dikenalkan pada anak selain melalui nyanyian di perlihatkan pula tulisannya dalam media big book atau pun media lainnya. Pada saat puisi lagu ini di nyanyikan guru ataupun orang tua melafalkan syairnya dengan jelas dan benar sehingga anak mendapatkan contoh yang benar dalam pelafalan kata demi kata.

Sedangkan dari segi puisinya, puisi lagu di atas untuk bait ke satu dan kedua memiliki akhiran fonem i, sedangkan untuk baris ke tiga dan keempat memiliki akhiran fonem u, atau bisa dikatakan bersajak aa bb. Sehingga membuat puisi sajak di atas semakin indah dan enak untuk dinyanyikan serta sarat dengan unsur pendidikan terutama yang berkaitan dengan kesehatan atau ada pada tema aku di dalam kurikulum pendidikan anak usia dini.

\author{
Topi Saya Bundar \\ Cip : Pak Kasur \\ Topi saya bundar \\ Bundar topi saya \\ Kalau tidak bundar \\ Bukan topi saya
}

Puisi lagu Topi Saya Bundar, cocok untuk anak usia 2-4 tahun dikarenakan pada syair puisi lagu ini ada pengulangan kata serta permainan kata yang indah. Pada setiap baitnya, mengenalkan pada anak bahwa topi yang dimilikinya bentuk bundar, kalau bentuknya tidak bundar bukanlah topinya. Selanjutnya kosakata baru yang dapat dikenalkan pada anak yaitu topi dan bentuk bundar. Sebaiknya ketika guru ataupun orang tua menyanyikan lagu ini disertai dengan gerakan atau membawa serta topi ataupun benda lain yang berbentuk bundar. Dari segi puisinya terlihat jelas pada akhiran fonem yang sama antara bait pertama dan ketiga yaitu $r$ dan bait kedua dengan keempat berakhiran a. yang menambah indah puisi lagu di atas setiap bait terdiri dari tiga suku kata yang mirip dan berulang sehingga hal ini membuat anak mudah mengingatnya. Larik-larik pada puisi lagu ini diperindah dengan adanya aliterasi perulangan bunyi konsonan.

Naik delman cip : Pak Kasur Pada hari minggu ku turut ayah ke kota Naik delman istimewa ku duduk di muka Ku duduk samping pak kusir yang sedang bekerja 
Mengendali kuda supaya baik jalannya

Tuk tik tak tik tuk tik tak tik tuk tik tak tik tuk Tuk tik tak tik tuk tik tak swara saptu kuda

Puisi lagu dengan judul Naik Delman ciptaan Pak Kasur, menceritakan tentang kegiatan hari minggu sang anak dan ayah yang menyenangkan dan seru yaitu naik delman. Pada puisi lagu ini kosakata yang dapat dikenalkan yaitu : hari minggu, kota, ayah, delman, istimewa, kusir, kendali, bagian muka dari delman, juga suara kaki kuda. Pada dasarnya anak menyukai kegiatan naik delman karena dapat berinteraksi langsung dengan kuda serta dapat merasakan semilirnya angin ketika menaiki delaman dan tak lupa sensasi yang paling menyenangkan adalah mendengar sepatu kuda. Melalui puisi lagu ini dapat pula dikenalkan bagaimana delman dapat melaju dan siapakah pengemudi delman. Puisi lagu naik delman biasanya dimasukkan pada tema kendaraan. Puisi lagu dapat di perkenalkan pada anak melalui nyanyian seraya menaiki delman ataupun membuat permainan yang serupa dengan kegiatan naik delman. Sedangkan dari sisi puisinya, terlihat dengan jelas semua bait syair lagu berakhiran fonem a. dan puisi lagu ini bertambah keindahananya dengan adanya efek eksploitasi bunyi sepatu kuda yang disenangi oleh anak-anak sehingga walaupun anak tidak dalam keadaan menaiki delman tapi ketika anak melalakukan puisi lagu seraya bergerak mereka seakan-akan merasakan hentakan kaki kuda yang berbunyi tuk tik tak tik tuk.

\section{Kucingku Cip: Pak Kasur \\ Kucingku belang tiga \\ Sungguh manis rupanya \\ Meong-meong bunyinya \\ Tanda lapar perutnya}

Puisi lagu di atas cocok di sampaikan pada anak usia 2-3 tahun, karena pada syairnya terdapat pengenalan jenis kucing dan suara kucing, dimana kucing merupakan salah satu binatang kesayangan anak, dan mereka menyukai suara dan bulunya yang halus. Kosakata yang dapat dikenalkan melalui puisi lagu adalah kucing, warna belang, bunyi kucing, perut dan lapar. Puisi lagu kucingku berakhiran fonem a, dan bersajak aa. Puisi lagu ini dapat membangkitkan rasa senang dan keinginan anak untuk mengetahui lebih lanjut tentang kucing. Eksploitasi tiruan bunyi kucing yaitu meong-meong pun ada di dalam puisi lagu ini sehingga membuatnya lebih menarik dan disukai anak, hal ini disebut juga anomatope. Dan melalui ketukan irama yang lambat menjadikan anak mudah mengikuti pelafalan syairnya dan mendendangkannya.

\section{Peramah dan Sopan Cip : Pak Dal}

Bukan yang congkak bukan yang sombong Yang disayangi handai dan taulan Hanya anak yang tak pernah sombong Rajin bekerja peramah dan sopan

Peramah dan sopan itulah judul puisi lagu di atas, maka syair lagunya berisikan mengenai sifat orang yang baik dan yang sombong. Melalui puisi lagu ini dapat dikenalkan kosakata congkak, sombong, rajin, peramah, dan sopan pada anak. Guru ataupun orang dewasa bisa menjelaskan makna dari syair puisi lagu pada anak melalui gerakan dalam nyanyian ataupun melalui sandiwara boneka yang mudah dipahami oleh anak. Puisi lagu ini bersajak a b a b, dan berakhiran fonem $g$ untuk bait kesatu dan ketiga, sedangkan pada bait ke dua dan keempat berakhiran $n$. Puisi lagu memiliki ketukan irama yang agak cepat sehingga membuat anak-anak semangat untuk mendendangkannya.

Melalui puisi lagu anak dapat mengenal dan memahami banyak kosakata baru serta makna yang ada dalam kosakata tersebut secara utuh. Puisi lagu menciptakan suasana belajar yang nyaman dan ringan karena selain belajar kosakata melalui lariklarik syair anakpun dapat mendendangkan syair-syair puisi dengan penuh gerakan kegembiraan. Puisi lagu selain menjadi cara untuk mengenalkan kosakata pada anak usia dini, puisi lagu pun bisa menjadi salah satu teknik untuk mengenalkan berbagai unsurunsur pendidikan yang sesuai dengan perkembangan anak sesuai dengan kurikulum anak usia dini. 


\section{Kesimpulan}

Peranan bahasa dalam kehidupan anak sangatlah penting. Ide dan gagasan dapat disampaikan anak melalui kemampuan bahasa yang dimilikinya. Agar anak mampu berbahasa sekaligus dapat berkomunikasi dengan baik maka anak membutuhkan pembedaharaan kosakata yang cukup banyak. Melalui pembendaharaan kosakata yang banyak anak dapat memahami berbagai makna yang di dengar dan di terimanya selama menjalani awal-awal kehidupan di usia dini.

Dalam menyampaikan berbagai hal yang berkaitan dengan anak usia dini haruslah menggunakan pendekatan, metode dan berbagai teknik yang sesuai dengan perkembangan anak. Yaitu pendekatan, metode dan teknik yang menyenangkan, menarik dan memberikan kenyaman bagi anak.

Puisi lagu merupakan salah satu teknik yang dapat dipilih oleh para orang tua dan guru anak usia dini untuk mengenalkan kosakata pada anak. Melalui puisi lagu selain anak belajar kosakata anakpun akan di kenalkan pada permainan bahasa, nyanyian dan gerakan yang berupa tarian agar kosakata yang ada pada setiap larik puisi lagu mudah dipahami, sehingga pembelajaran bermaknapun dapat diperoleh oleh anak.

\section{Daftar Pustaka}

Al-Khuly. (2002). Model Pembelajaran Bahasa Arab. Bandung : Pusata Studi Islam dan Bahasa Arab

Azhar. 2003. Bahasa Arab dan Metode Pengajarannya. Jakarta : Bumi Aksara

Balai Bahasa. (2010). Mempelajari Kosakata. UPI : Bandung

Beaty. J. (2013). Observasi Perkembangan Anak Usia Dini. Jakarta : Kencana.

Dhieni, N. (2008). Metode Pengembangan Bahasa. Jakarta : Universitas Terbuka

Inten, dkk. (2016). Literasi Dini Melalui Teknik Bernyanyi. Jurnal Al-Murabbi.Vol 3 No. 1 Juli. STKIP Pembangunan Ngawi Jawa Timur.

Inten. D. (2015). The Effect Of Music Adan Movements Towards Arabic's
Vocabulary Mastery In Early
Childhood. Prosiding Internasional Chill will Being. Bandung; PGPAUD Universitas Islam Bandung.

Inten \& Mulyani. (2016) Literasi Bahasa Sunda Melalui lgel Mang Koko. Seminar Internasional Bahasa IbuSebagai Sumber Budaya Literasi. Bandung : Unpad Press.

Inten. D. (2017). Peranan Keluarga Dalam Menanamkan Literasi Pada Anak. Vol 1 No 1 Juni. Program Studi PGPAUD Universitas Islam Bandung.

Inten. D. Pengembangan Keterampilan Berkomunikasi Anak Usia DiniMelalui Metode Bermain Peran. Jurnal Mediator Vol 10 (1) Juni Fakultas IImu Komunikasi Universitas Islam Bandung.

Jamaris. (2005). Peningkatan Penguasaan Kosakata Bahasa Inggris Melalui Permainan. Jurnal Pendidikan Anak Usia Dini. Volume 3, No, 2 Mei 2005. Program Pasca Sarjana Universitas Negeri Jakarta.

Masnipal. (2017). Profesionalisme guru PAUD. Bandung : Gramedia.

Madyawati. (2016). Strategi Pengembangan Bahasa Pada Anak. Jakarta : Kencana. Nurgiantoro. B. (2016). Sastra Anak. Yogya : Gadjah Mada Press.

Otto. (2015). Perkembangan Bahasa Pada Anak Usia Dini. Jakarta : Kencana

Santrock. (2007). Perkembangan Anak. Bandung : Erlangga.

Tarigan. (1996). Pengajaran Kosakata. Bandung : Angkasa.

Uyu \& Agustin. (2011). Penilaian Perkembangan Anak Usia Dini. Bandung : Refika Aditama. 